\title{
Ethiopian Chronicle.A Few Lines on the Possible Place Where Humanity Was Born
}

\begin{abstract}
In spite of being the possible cradle of the human race, Ethiopia is far from being a socalled "important country" in short sighted times like ours. The era of dehumanization of man is in full force. In this article we will talk about a country that highlights the fact that human life, although being short, transitory and full of uncertainty, can be lived with hope and dignity.
\end{abstract}

Keywords: Ethiopia, Geology, Culture, History, Endurance

Like some high official, you have to tell your brain: "Do it. Come on. I have to do it".

Haile Gebrselassie
Volume 2 Issue 5 - 2018

\author{
João Vicente Ganzarolli de Oliveira \\ Professor and Researcher of the Tércio Pacitti Institute of the \\ Federal University of Rio de Janeiro, Brazil
}

\begin{abstract}
Correspondence: João Vicente Ganzarolli de Oliveira, Professor and Researcher of the Tércio Pacitti Institute of the Federal University of Rio de Janeiro, Brazil, Tel +552I- 3938-
\end{abstract} 9600, Email jganzirolli@usa.com

Received: October 09, 2018 | Published: October 22, 2018

\section{Editorial}

Little is said about Ethiopia in short sighted times like ours. Paradoxically, these are times in which the opportunities of acquiring knowledge seem unbounded and the advances of the communication media are prodigious. The cost is high: computing revolution made the computers ends in themselves; more and more we are enthralled by virtual experiences, and less and less we experience the real world. Communication (taken as the human process of conveying and receiving useful information) and interest in beneficial knowledge is in decline among us, human beings. We bypassed the essence of things and made do with their ancillary and not infrequently illusionary aspects. Too many possibilities of choosing how to spend our time undermine our very capacity of enjoying time - never forgetting that time is the raw material of what we call life. The era of dehumanization of man is in full force. Let us talk about Ethiopia, possible cradle of humanity and a country that highlights the fact that human life, although being short, transitory and full of uncertainty, can be lived with hope and dignity.

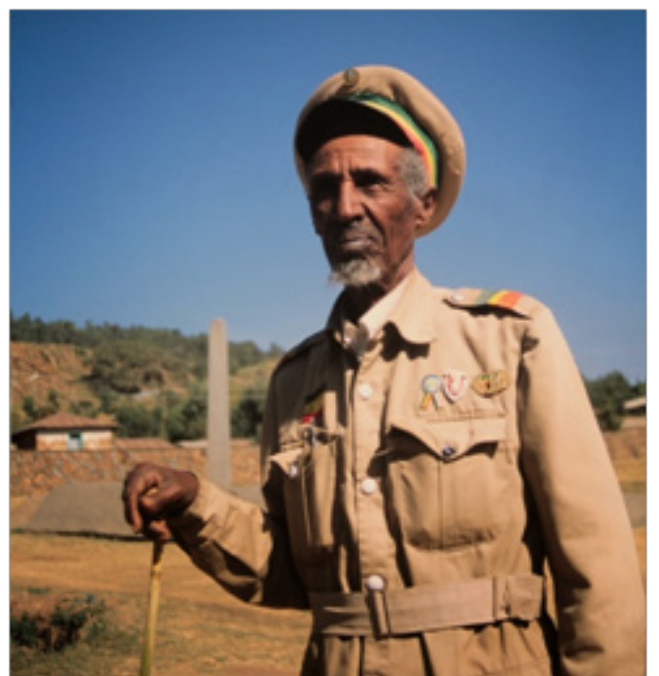

We are all Africans (Ethiopians?), in what concerns our ancestry. (Photo taken by the Author).
Few places on earth could match Ethiopia's importance in what regards the closeness of the relationship between geology and human life. About thirty-five million years ago, tectonic forces literally began to rip apart the African plate, from the Red Sea region until Mozambique; ${ }^{1}$ extending over thousands of miles, the East African Rift was born. In the same geological context, mountains started to grow in Ethiopia, Kenya and Tanzania, becoming high enough to divert the winds that came from the west, bringing moisture and rain. As a result, the far eastern part of Africa became drier: clusters of high trees started to disappear, thus promoting evolutionary adaptations and the appearance of a large number of new ecosystems; the ground was being prepared for the emergence of the African savannah, habitat in which the first hominids were born, about seven million years ago. We are all Africans, perhaps Ethiopians, in what concerns our ancestry.

Hunger and misery have deep historical (and even pre-historical) roots in Ethiopia (now one of the poorest countries in the world) and in Africa itself; Egyptian reports old of almost six thousand years already refer to both scourges. Together with Djibouti, Eritrea and Somalia, Ethiopia is part of the East African peninsula called Horn of Africa; surrounded by the Red Sea (itself a geological offspring of the same geological metamorphosis mentioned above), and by more than one desert, Ethiopia looks like an oasis. Ethiopians' land adorned with volcanos, green plateaus, mild climate, high mountains and countless gorges - has always sparked greed and envy among their more aggressive and less industrious neighbours. As far back as the $4^{\text {th }}$ century, Christianity became the official religion of what is now Ethiopia. ${ }^{2}$ Soon, however, dark clouds appeared on the horizon:

\footnotetext{
1"Plate tectonics (from the Late Latin tectonicus, from the Greek: $\tau \varepsilon \kappa \tau o v i k o ́ s$, pertaining to building) is a scientific theory describing the large-scale motion of seven large plates and the movements of a larger number of smaller plates of the Earth's lithosphere, since tectonic processes began on Earth between 3 and 3.5 billion years ago. The model builds on the concept of continental drift, an idea developed during the first decades of the 20th century. The geoscientific community accepted plate-tectonic theory after seafloor spreading was validated in the late 1950s and early 1960s" (R. C. Bostrom et alii. https:// en.wikipedia.org/wiki/Plate_tectonics).

${ }^{2}$ Tradition states that the very first seed of Christian faith was sown in Ethiopia by St Matthew the Apostle - soon followed in his work of Evangelization by St. Ephigenia, a virgin converted to Christianity and then consecrated to God by him, according to the Golden Legend - a once famous collection of hagiographies written or, more accurately, compiled by Blessed Jacobus de
} 
started in the $7^{\text {th }}$ century, while Mohammed was still alive, the ever increasing Islamic invasions have caused conflicts that persist until nowadays in Ethiopia. ${ }^{3}$ To this already tragic scenario, we must add: a) the Fascist Italian aggression and occupation (1935-1941); b) the communist dictatorship of Mengistu Mariam (1974-1991), unable to address the problems associated with the drought of 1981-1985, not to mention the failure of his plan of collectivization of Ethiopian agricultural sector; c) the war against neighbouring Eritrea, from 1998 to 2000 , with the final peace only recently agreed.

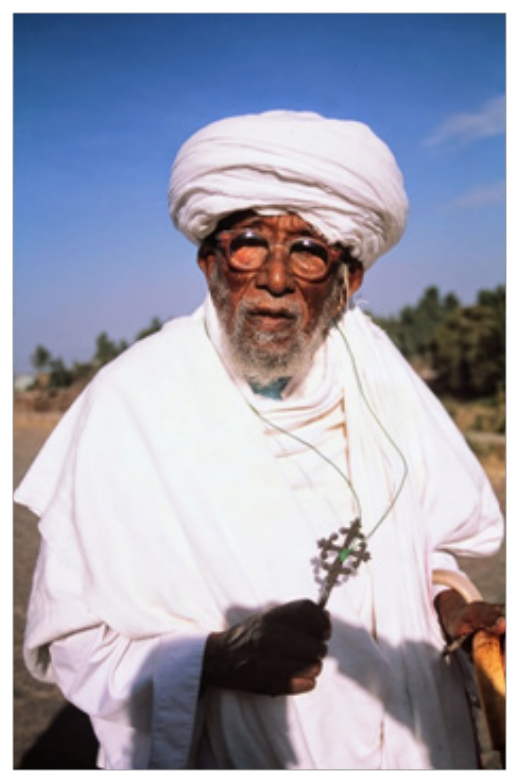

"Many are invited, but few are chosen" (Mt 22, 14). (Photo taken by the Author).

From Ethiopia - whose cultural traditions may traditions may date back 5,000 years - seems to have come the famous Queen of Sheba, who visited the kingdom of Israel at the time Solomon reigned (970 $931 \mathrm{BC}) .{ }^{4}$ Such is the fundamental basis for the theories according to which Ethiopians are direct descendants of Solomon and that the Ark of the Covenant was transported to Ethiopia. Tradition states that it rests on Ethiopian ground until today, hold by the church of Our Lady Mary of Zion, built in the $17^{\text {th }}$ century in the city of Axum, former capital of the powerful kingdom of the same name, whose origins date back to the third century BC. ${ }^{5}$ Nothing is more characteristic

Varagine (c. 1230 - 1298) (see Hilary Maddocks et alii. https://en.wikipedia. org/wiki/Golden_Legend).

3“'In March 2011, after a Christian was accused of desecrating a Koran, thousands of Christians were forced to flee their homes in western Ethiopia when Muslims majorities set fire to roughly fifty churches and many Christian homes. Sources claim at least one Christian was killed, many more were severely injured, and from three to ten thousand were displaced by the Muslims raids and riots" (Raymond Ibrahim Crucified Again. Exposing Islam's New War on Christians, New York/Washington, Gatestone Institute/Regnery, 2013, p. 63; see also Udo Ulfkotte. Mekka Deutschland. Die stille Islamisierung, Rottenburg, Kopp, 2015, pp. 107-126; and Alberto da Costa e Silva. A enxada e a lança: a África antes dos portugueses, São Paulo, EDUSP/Nova Fronteira, 1992, p. 263 et passim.

${ }^{4} 1 \mathrm{Kgs} 10,1-13$.

5"The Kingdom of Aksum (also known as the Kingdom of Axum, or the Aksumite Empire) was an ancient kingdom in what is now northern Ethiopia and Eritrea. Ruled by the Aksumites, it existed from approximately $100 \mathrm{AD}$ to $940 \mathrm{AD}$. (...) It became a major player on the commercial route between the Roman Empire and Ancient India. (...) The Manichaei prophet Mani (died 274 of Ethiopian Christianity (which is of Coptic, i.e, Egyptian, origin) than the almost one thousand years old rock-hewn churches of Lalibela, city that substituted Axum as capital. It was founded by the king of the same name in the thirteenth century; King Lalibela, aka "the Ethiopian St. Louis", made his capital a remarkable centre of pilgrimage, turned out to become the African Jerusalem. ${ }^{6}$ At the same time, began the Ethiopian Literary Renaissance, which lasted until the $19^{\text {th }}$ century. Ethiopian sacred music and literature have their roots in the old Christian rites performed in Egypt. Another uniqueness of Ethiopia lies in the fact of being the only sub-Saharan country to have created and developed a written language, the Ge'ez, "which remains until today as the main language used in the liturgy of the Ethiopian Orthodox Tewahedo Church, the Eritrean Orthodox Tewahedo Church, the Ethiopian Catholic Church, the Eritrean Catholic Church, and the Beta Israel Jewish community"?

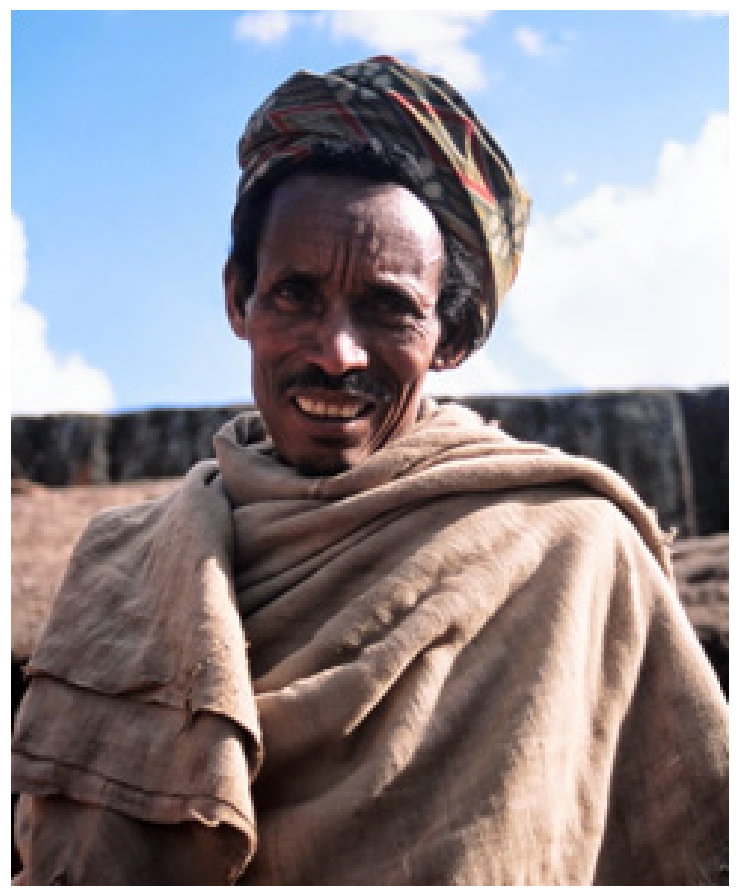

Invaded and harassed by Islam from all sides, Ethiopians persevere in the Christian Faith, "whether it is convenient or inconvenient"

( $2 \mathrm{Tm} 4,2)$. (Photo taken by the Author).

In the sixth century d. C., the Byzantine traveller Cosmas Indicopleustes was fascinated by Ethiopia and said he had seen beautiful cities within its territory; this is one of the reasons why Africanists speak of an Ethiopian miracle. Ethiopia is also the land of Prester John, a legendary (?) priest-king who fuelled European's

AD) regarded Axum as one of the four great powers of his time, the others being Persia, Rome, and China" (Butzer, Karl W. et alii. https://en.wikipedia. $\mathrm{org} /$ wiki/Kingdom_of_Aksum).

${ }^{6 "}$ During the reign of Gebre Mesqel Lalibela, a member of the Zagwe dynasty who ruled Ethiopia in the late 12th century and early 13 th century, the current town of Lalibela was known as Roha. (...) Lalibela, revered as a saint, is said to have seen Jerusalem, and then attempted to build a new Jerusalem as his capital in response to the capture of old Jerusalem by Muslims in 1187. Each church was carved from a single piece of rock to symbolize spirituality and humility. Christian faith inspires many features with Biblical names - even Lalibela's river is known as the River Jordan. Lalibela remained the capital of Ethiopia from the late 12th into the 13th century“ (David Phillipson et alii. https://en.wikipedia.org/wiki/Lalibela\#History).

${ }^{7}$ Wolf Leslau et alii. https://en.wikipedia.org/wiki/Ge\%27ez. 
imagination during half a millennium, that is, between the $12^{\text {th }}$ and the $17^{\text {th }}$ centuries ${ }^{8}$. Europeans viewed him as a potential ally against Islam, who was striking unremittingly in Africa, in Asia, as well as in Europe itself. Tradition says that Prester John, descendant of one of the Three Magi, was a powerful, righteous and virtuous monarch, and that in his palace resided the Patriarch of the Saint Thomas Christians. ${ }^{9}$ It was also believed that within his kingdom there were wonders such as the Gates of Alexander ${ }^{10}$, the Fountain of Youth ${ }^{11}$ and the Terrestrial Paradise. Was Prester John a legendary version of the great Ethiopian king of flesh and blood Gebre Mesqel Lalibela? Who knows? This is just one among many question about Ethiopia that are still left unanswered.

Reaching the kingdom of Prester John was one of the key objectives of the Great European (namely Iberian, British, French and Dutch) Navigations, which ended up by achieving not only the discovery of brand-new worlds (notably America, Oceania, and Antarctica), but also a much better knowledge of Asia, Africa and of Europe itself. Having seen some of the myths, legends, as well as geological and historical facts, it is worth recalling the Ethiopian athlete Haile Gebrselassie (1973), typical example of endurance. ${ }^{12}$ Gebrselassie

\footnotetext{
${ }^{8 " P r e s t e r ~ J o h n ~(L a t i n: ~ P r e s b y t e r ~ J o h a n n e s) ~ w a s ~ a ~ l e g e n d a r y ~ C h r i s t i a n ~}$ patriarch, presbyter (elder) and king who was popular in European chronicles and traditions from the 12 th through the 17 th centuries. He was said to rule over a Nestorian (Church of the East) Christian nation lost amid the Muslims and pagans of the Orient, in which the Patriarch of the Saint Thomas Christians resided. The accounts are varied collections of medieval popular fantasy, depicting Prester John as a descendant of the Three Magi, ruling a kingdom full of riches, marvels, and strange creatures. At first, Prester John was imagined to reside in India; tales of the Nestorian Christians' evangelistic success there and of Thomas the Apostle's sub-continental travels as documented in works like the Acts of Thomas probably provided the first seeds of the legend. After the coming of the Mongols to the Western world, accounts placed the king in Central Asia, and eventually Portuguese explorers convinced themselves that they had found him in Ethiopia“" (Beckingham, Charles et alii. https:// en.wikipedia.org/wiki/Prester_John).

9"The Saint Thomas Christians, also called Syrian Christians of India, Nasrani, Malankara Nasrani or Nasrani Mappila, are an ethno-religious community of Malayali Syriac Christians from Kerala, India, who trace their origins to the evangelistic activity of Thomas the Apostle in the $1^{\text {st }}$ century. The terms Syrian or Syriac relate not to their ethnicity but to their historical, religious and liturgical connection to Syriac Christianity. The term Nasrani was derived from Semitic languages like Syriac (كنارصن) and Arabic (ىر اصن) and refers to Christians in general" (Mar Aprem et alii. https://en.wikipedia.org/wiki/ Saint_Thomas_Christians).

${ }^{10}$ "The Gates of Alexander were a legendary barrier supposedly built by Alexander the Great in the Caucasus to keep the uncivilized barbarians of the north (typically associated with Gog and Magog) from invading the lands to the south. The gates were a popular subject in medieval travel literature, starting with the Alexander Romance in a version from perhaps the $6^{\text {th }}$ century" (Richard Stoneman et alii. https://en.wikipedia.org/wiki/Gates of Alexander) ${ }_{116}$ The Fountain of Youth is a spring that supposedly restores the youth of anyone who drinks or bathes in its waters. Tales of such a fountain have been recounted across the world for thousands of years, appearing in writings by Herodotus $\left(5^{\text {th }}\right.$ century $\left.\mathrm{BC}\right)$, the Alexander Romance $\left(3^{\text {rd }}\right.$ century $\left.\mathrm{AD}\right)$, and the stories of Prester John (early Crusades, $11^{\text {th }} / 12^{\text {th }}$ centuries AD). Stories of similar waters were also evidently prominent among the indigenous peoples of the Caribbean during the Age of Exploration (early $16^{\text {th }}$ century), who spoke of the restorative powers of the water in the mythical land of Bimini" (Pedro Martir de Anglería et alii. https://en.wikipedia.org/wiki/Fountain_of_Youth). ${ }^{12} \mathrm{See}$, for instance, https://en.wikipedia.org/wiki/Endurance (film).
}

overcame adversities of all kinds and became one of the greatest long distance runners of all times and places. He is the living proof that, just as the excess of facilities can cause laziness, turning therefore into a handicap, adversities and difficulties in general, depending on how they are envisaged, can serve as a stimulus for being a winner not only in the Olympic Games, but also in life itself.

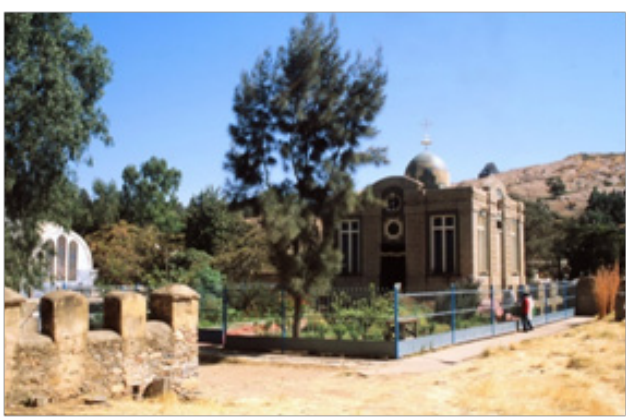

Church of Our Lady Mary of Zion, in Axum, Ethiopia (Photo taken by the Author).

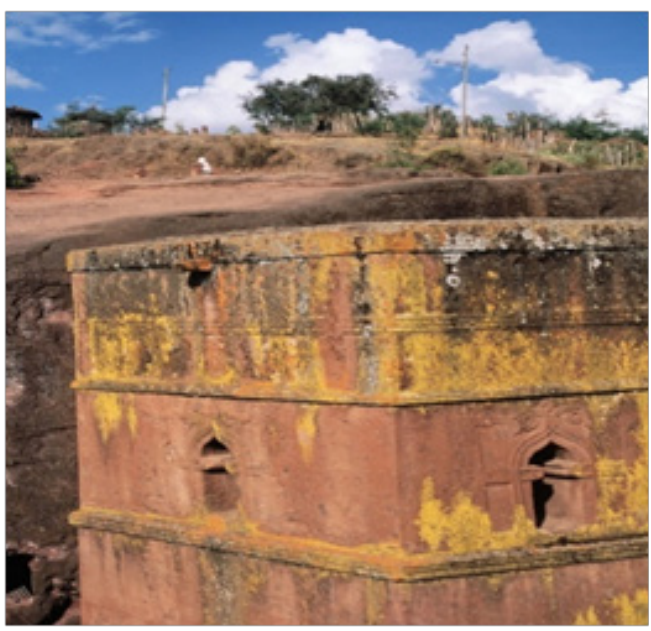

Lalibela (Photo taken by the Author).

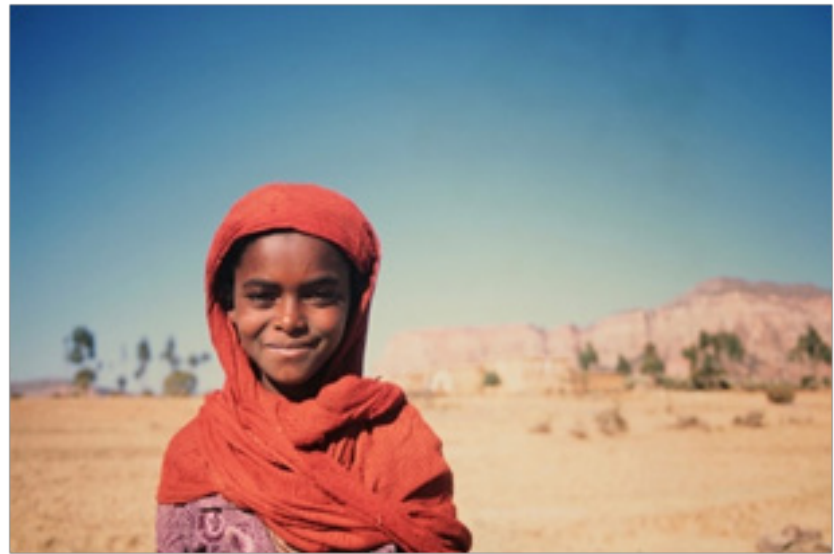

"An awareness of our past is essential to the establishment of our personality and our identity as Africans”, said Haile Selassie (I892-1975), Emperor of Ethiopia. (Photo taken by the Author) 


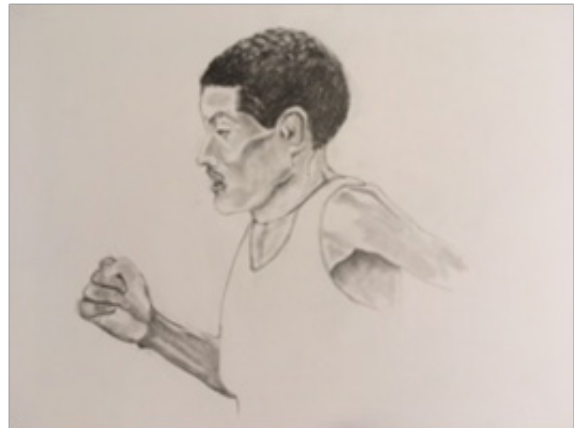

\section{Acknowledgements}

None.

\section{Conflict of interest}

The author declares there is no conflict of interest.

Haile Gebrselassie (Drawing made by the Author). 